\title{
Financial Knowledge and Millennials Investing Behaviors in Indonesia
}

\author{
Aang Kunaifi ${ }^{1}$, Ahnan Naufal Fadlil Akbar ${ }^{1}$ \\ ${ }^{1}$ Department of Business Management, Institut Teknologi Sepuluh Nopember (ITS) Surabaya, 60111, \\ E-mail: aang_kunaifi@mb.its.ac.id
}

\author{
Diterima: 08/08/2018 \\ Direview: 18/10/2019 \\ Diterbitkan: 28/11/2019 \\ Hak Cipta (C) 2019 oleh Penulis (dkk) dan Jurnal \\ Sosial Humaniora (JSH) \\ *This work is licensed under the Creative \\ Commons Attribution International License (CC \\ BY 4.0). \\ http://creativecommons.org/licenses/by/4.0/ \\ cc) (†) Open Access
}

\begin{abstract}
Subject Area: Economy (Ekonomi)
Abstract

This research aims to investigate investment behavior in Indonesia millennial generation. Three variables are used to explain millennial behavior to have an investment account or unit. Consistent multivariate result found that financial knowledge is positively associated with investment behavior. The results also found that personal factors such as age group and gender have relationship on investment behavior. Junior age group and female havemore likely to have an investment account or unit.
\end{abstract}

Keywords: financial knowledge; age group; gender; millennial.

\section{Introduction}

A recent survey conducted in by IDN Research Institute explains that Indonesian millennials generation is quite consumptive generations (Utomo, 2019). The survey explains that common Indonesia millennial generation is drained for monthly expenses and just $10.7 \%$ allocate the income for saving and $2 \%$ allocate to investment.

Investing for wealth management is good behavior begin early that everyone needs (Wang, 2011). Young people with investment aware can reach their financial goals. But, investing is also a more difficult activity that requires additional knowledge than simply having a saving account (Copur \& Gutter, 2019). Investing in the young generation like millennial generation have more factor to be investigate.

Prior study had been conducted to investigate financial knowledge impact to investment behavior. Using survey data, Wang (2011) explain that knowledge had been influencing on younger generations investing behavior. Financial knowledge in other research, also called financial literacy was positively associated with managing behavior (Henager \& Cude, 2016); (Azhar, Azilah, \& Syafiq, 2017). Its supposedly to explain that financial knowledge as a social factor will associate with Indonesian investment behavior.

Another factor that impacts investment behavior is personal factor. Personal factor includes age and gender that will impact on well-being decision making. Using experiment research Goldsmith (2006) explain that women knew investment less than men. Research by Wang (2011) explain that experience (age) and gender have influence on investment behavior. Henager \& Cude (2016) explain that age group was progressively more likely to engage in long term-behavior included investing behavior. 
The purpose of this research is to explore determinant investment behavior in Indonesian millennial generation. We examine the relationship between financial knowledge, personal factors such as age group and gender to their investment behavior. This study can be an important insight for policymaker and financial practitioners.

\section{Research Method}

The research conducted at Indonesian millennials generation. The current study is based on micro-level data of personal investment behavior. This research conduct in Indonesian millennials in range age 20-35 years of age. A total 653 set of questionnaires has been collected online survey in 63 city in Indonesian.

This study measured a dependent variable that reflects investing behavior. Investing behavior measure by ownership an investment account or unit (Copur \& Gutter, 2019). The primary focus of this study as an independent variable was financial knowledge. Financial knowledge measures are based on self-reported estimated as subjective financial knowledge (Halko, Kaustia, \& Alanko, 2012). Financial knowledge was based on the six questions refer to subjective knowledge using a likert-type scale that range 1 to 5 adapted from Flynn \& Goldsmith (1999) and then constructed as a financial knowledge index. Subjective knowledge originally has been used to explain in consumer behavior studies and can be adapted as common way to explain subjective knowledge in other areas study like financial knowledge. The six questions of financial knowledge was constructed using the iterated principal factor method to get a financial knowledge index consistent with Kim, Anderson, \& Seay (2019). Factor loading are generated using iterated principal factor method. Table 1 presents factors loading of financial knowledge question. The personal factor were included as independent variable in the analysis were dichotomized and define as follows: age groups (20-27 as junior millennials $=0$, 28-35 as senior millennials $=1$ ) and gender (male $=1$, female $=0$ ). The analysis employed logit (binary) regression for the analysis because the nature of the dependent variable is binary. Since the dependent variable is binary (ownership investment account or unit), we applied logit regression with the following investment behavior model to test the hypothesis:

INVEST $=\beta_{0}+\beta_{1}$ FK $+\beta_{2}$ AgeGroup $+\beta_{3}$ Gender $+\varepsilon$

\section{Result and Discussion}

Table 1 present the basic descriptive statistics of regressions variable. The mean of the composite score financial knowledge was 3.19, and it show that Indonesian millennial have a positive perception in their financial knowledge. But, only $15.6 \%$ of millennial had figured out-owned investment account or unit. The sample dominate by the female respondent $(61,26 \%)$ and age group dominate by junior millennial $(94.18 \%)$.

Table 2 provides result from the regression to test the association between financial knowledge, personal factor and their investment behavior. The analysis shows that a pseudo R-square of 0.242 and a Chi-square of 98.636, the model have statistically significant and can differentiate between millennial have an investment account or unit from millennial don't have an investment account or unit. 
The coefficient for the variable financial knowledge is positively significant at $1 \%$ level $\left(\beta_{1}=0.9131\right.$, Wald $=40.782$ ). It's suggested that millennial with high financial knowledge are more likely to choose spending investment account or unit. The odds ratio of 2.537 for the relationship between financial knowledge and investment behavior indicates that the odds were more than two times higher than respondents who reported subjective financial knowledge perception had engaged in the investment behavior relative to respondents with lower perception.

Table 1. Descriptive of data for test

\begin{tabular}{|c|c|c|c|c|c|}
\hline Variable & Frekuensi & Persentase $(\%)$ & Mean & Factor Loading & $\mathbf{N}$ \\
\hline \multicolumn{6}{|l|}{ Investment Behavior } \\
\hline Don't have account or unit & 551 & $84.40 \%$ & & & \\
\hline Have Account or Unit & 102 & $15.60 \%$ & & & \\
\hline Total/ N & 653 & $100.00 \%$ & & & \\
\hline \multicolumn{6}{|l|}{ Gender } \\
\hline Male & 253 & $38.74 \%$ & & & \\
\hline Female & 400 & $61.26 \%$ & & & \\
\hline Total/ N & 653 & $100.00 \%$ & & & \\
\hline \multicolumn{6}{|l|}{ Age Group } \\
\hline 20-27 (Junior millennial) & 615 & $94.18 \%$ & & & \\
\hline 28-35 (Senior millennial) & 38 & $5.82 \%$ & & & \\
\hline Total/ N & 653 & $100.00 \%$ & & & \\
\hline \multicolumn{6}{|l|}{ Financial Knowledge } \\
\hline $\mathrm{fk} 1$ & & & 3,39 & .810 & 653 \\
\hline $\mathrm{fk} 2$ & & & 3,37 & .808 & 653 \\
\hline $\mathrm{fk} 3$ & & & 2,89 & .800 & 653 \\
\hline $\mathrm{fk} 4$ & & & 3,4 & .821 & 653 \\
\hline $\mathrm{fk} 5$ & & & 3,18 & .769 & 653 \\
\hline fk6 & & & 2,92 & .744 & 653 \\
\hline Total mean & & & 3,19 & & \\
\hline
\end{tabular}

The association of financial knowledge and investment behavior is positively. This research finding consistent with Halko et al., (2012) that explain investment knowledge have a positive impact on investment in stock. Financial knowledge has a significant affect the investment awareness (Azhar et al., 2017). Financial knowledge has impact on good financial behavior (Kim et al., 2019). The financial knowledge will make someone seriously financial planning. The financial knowledge will guide millennial on how to manage their money and make decision to reach their future financial goal and begin to invest early.

Table 2. Ordered Logistic Regression with Investment Behavior as Dependent Variable (N 653)

\begin{tabular}{lrrr|}
\hline \multicolumn{1}{c}{ Variable } & \multicolumn{1}{c}{ Coefficient } & Wald & Odds Ratios \\
\hline Constant & -0.412 & 1.100 & 0.294 \\
FK & $0.931^{* * *}$ & 40.782 & 2.537 \\
AgeGroup & $-1.167 * * *$ & 8.906 & 0.311 \\
Gender & $-0.981^{* * *}$ & 16.448 & 0.375 \\
\hline
\end{tabular}

(Note: The coefficient that are significant at $1 \% * * *$ ) 
The coefficient of personal factor was included age group and gender variable explain that age group (junior and senior age millennial) is negatively significant at $1 \%$ level $\left(\beta_{2}=-1.167\right.$, Wald $\left.=8.906\right)$. It's suggested that senior age millennial are less likely to have an investment account or unit. But in junior millennial is more likely to choose to spend in an investment account or unit. The odds ratio of 0.311 (below 1) for the relationship between age group and investment behavior clarify the negative relationship.

The Age group in this study can be proxy to the experience and risk profile in Indonesian millennial generation. The junior millennial age group more likely to have investment account or unit clarify that junior millennial is risk-taker. Dohmen et al. (2011) explain that attitude varies over the life cycle, risk propensity decreases with age. The young generation have more risk profile in life cycle. Investment decision is relatively more risk than saving decision making because type of investment, concept and how information should be taken will affect their investment portfolios. Consistent to the study Barasinska \& Schäfer (2017) assert in Austria, age has negative significant on stock investment.

The other personal factor in this research is gender. The gender variable is negatively significant at $1 \%$ level $\left(\beta_{3}=-0.981\right.$, Wald $\left.=16.448\right)$. It's explain that female millennial is more likely invest than male millennial. The odds ratio clarify the negative relationship between gender and investment behavior.

Gender gap and gender chance to investment access in Indonesian millennial can be explained from this study. The previous study held by Barasinska \& Schäfer (2017) explain that individual have decided to invest when self-selection occurs. Women have self-selection to ownership assets independently. Indonesian female millennial was more likely to have an investment account or unit.

Investment decision can be an ambiguous judgment task and lets someone (individual) to conform their decision to group. Female millennial have self-selection in decision making to make investment decision making, but female can be more risk taking when interact with male in group (Castillo, Leo, \& Petrie, 2013). In assets market, male and female have same role in market without common public knowledge (Eckel \& Füllbrunn, 2017). It clarifies that the gender difference or gender gap in investment behavior Indonesian millennial generation is narrow. Female have the same chance to access investment product.

\section{Conclusion}

We found that investment behavior is predicted better by financial knowledge to increase the use of investment practice. The millennial must be convinced of their financial knowledge. The personal factor like age group and gender have significant impact on investment behavior. This finding important to financial practitioners. The financial practitioners can make junior millennial as a potential market to access financial investment product. Even so, the practitioners must give simply teaching them general skill as simply investing analytic to make the investment decision making. Our finding recommended the policymaker to make financial inclusion and empowering the young women to have more access in investing product.

A challenge for future research is to examine another personal subsystem variable including personality, financial priority, and personal finance management as a predictor in millennial financial behavior. Better financial knowledge can be used to measure financial knowledge in the millennial generation. The 
findings of this study may be not generalizable to all Indonesian millennial with more have characteristic and ethnic. The future research can use quota sampling in city or province in Indonesia and explore more personal factor like ethnic and demography to explore more generalizable finding in Indonesian millennial.

\section{References}

Azhar, Z., Azilah, N., \& Syafiq, A. (2017). Investment Awareness among Young Generation. Proceedings of the International Conference on Business and Management Research (ICBMR-17). https://doi.org/10.2991/icbmr-17.2017.12

Barasinska, N., \& Schäfer, D. (2017). Gender role asymmetry and stock market participation - evidence from four European household surveys. The European Journal of Finance, 24 (12), 1026-1046. https://doi.org/10.1080/1351847X.2017.1371622

Castillo, M., Leo, G., \& Petrie, R. (2013). Room Effects. GMU Interdisciplinary Center for Economic Science Department of Economics, Paper No. 13-17. Retrieved from http://edirc.repec.org/data/icgmuus.html

Copur, Z., \& Gutter, M. S. (2019). Economic, Sociological, and Psychological Factors of the Saving Behavior: Turkey Case. Journal of Family and Economic Issues, 40 (2), 305-322. https://doi.org/10.1007/s10834018-09606-y

Dohmen, T., Falk, A., Huffman, D., Sunde, U., Schupp, J., \& Wagner, G. G. (2011). Individual risk attitudes: Measurement, determinants, and behavioral consequences. Journal of the European Economic Association. https://doi.org/10.1111/j.1542-4774.2011.01015.x

Eckel, C. C., \& Füllbrunn, S. C. (2017). Hidden vs. known gender effects in experimental asset markets. Economics Letters, 156, 7-9. https://doi.org/10.1016/J.ECONLET.2017.04.009

Flynn, L. R., \& Goldsmith, R. E. (1999). A Short, Reliable Measure of Subjective Knowledge. Journal of Business Research, 46(1), 57-66. https://doi.org/10.1016/S0148-2963 (98)00057-5

Goldsmith, R. E. (2006). The Effects of Investment Education on Gender Differences in Financial Knowledge. Journal of Personal Finance, 5(2), 55-69.

Halko, M.-L., Kaustia, M., \& Alanko, E. (2012). The gender effect in risky asset holdings. Journal of Economic Behavior \& Organization, 83(1), 66-81. https://doi.org/10.1016/J.JEBO.2011.06.011

Henager, R., \& Cude, B. J. (2016). Financial Literacy and Long- and Short-Term Financial Behavior in Different Age Groups. Journal of Financial Counseling and Planning, 27(1), 3-19. https://doi.org/10.1891/1052-3073.27.1.3

Kim, K. T., Anderson, S. G., \& Seay, M. C. (2019). Financial Knowledge and Short-Term and Long-Term Financial Behaviors of Millennials in the United States. Journal of Family and Economic Issues, 40(2), 194-208. https://doi.org/10.1007/s10834-018-9595-2

Utomo, W. P. (2019). Indonesia Millennial Report 2019. Retrieved from https://cdn.idntimes.com/contentdocuments/indonesia-millennial-report-2019-by-idn-times.pdf

Wang, A. (2011). Younger Generations' Investing Behaviors in Mutual Funds: Does Gender Matter? The Journal of Wealth Management, 13(4), 13-23. https://doi.org/10.3905/jwm.2011.13.4.013 